\title{
Pengaruh Proses Fermentasi dan Non-Fermentasi serta Pengeringan dengan Metode Spray Drying terhadap Mutu Serbuk Minuman Instan dari Buah Naga Merah (Hylocereus polyrhizus) Effect of Fermentation and Non-Fermentation Processes and Drying with Spray Drying Method on the Quality of Instant Drink Powder from Red Dragon Fruit (Hylocereus polyrhizus)
}

\author{
Lukman Junaidia ${ }^{*}$, Hendra Wijayaa, Raisa Shafira Jarief ${ }^{b}$ dan Dudung Angkasa ${ }^{b}$
}

aBalai Besar Industri Agro (BBIA)

Kementerian Perindustrian, Jalan Juanda No. 11, Bogor, 16122

'Program Studi Ilmu Gizi, Fakultas Ilmu-Ilmu Kesehatan Universitas Esa Unggul Jalan Arjuna Utara No.9, Kebon Jeruk, Jakarta Barat.

\section{Riwayat Naskah:}

Diterima 052021

Direvisi 092021

Disetujui 102021
ABSTRAK: Konsumsi buah naga merah bermanfaat untuk meningkatkan kesehatan sistem pencernaan, mengurangi kolesterol dan mencegah konstipasi. Tetapi buah ini mudah rusak sehingga perlu dilakukan penelitian untuk meningkatkan nilai tambahnya. Penelitian ini bertujuan untuk mengetahui pengaruh proses fermentasi dan non fermentasi yang dikombinasikan dengan proses pengeringan menggunakan metode spray drying terhadap mutu serbuk minuman instan buah naga merah. Pada penelitian ini, jus buah naga merah yang diberi perlakuan dicampur air dengan rasio 1:3, dan dipasteurisasi pada suhu $80{ }^{\circ} \mathrm{C}$ terlebih dahulu, lalu didinginkan. Kemudian dilanjutkan dengan dua perlakuan, yaitu proses fermentasi anaerob menggunakan Saccharomyces cerevisiae pada suhu $25^{\circ} \mathrm{C}$ selama 10 hari, dan tanpa proses fermentasi. Serbuk minuman instan yang dihasilkan dari proses pengeringan spray drying dan dari dua perlakuan terdiri dari dua formula, yaitu minuman instan non fermentasi (F1) dan fermentasi (F2). Hasil organoleptik yang dianalisis dengan uji one way analysis of variance dan dilanjutkan uji lanjut Bonferroni, diperoleh hasil bahwa F1 lebih disukai panelis tidak terlatih daripada F2. Secara umum, perlakuan proses non fermentasi lebih berpengaruh terhadap mutu serbuk minuman instan buah naga merah yang terbentuk, dan formulanya (F1) lebih disukai oleh panelis, serta bisa diaplikasikan lebih lanjut.

Kata kunci: buah naga merah, fermentasi, non fermentasi, karakteristik mutu

ABSTRACT: Consumption of red dragon fruit is beneficial for improving the health of the digestive system, reducing cholesterol and preventing constipation. But this fruit is easily damaged so it is necessary to do research to increase its added value. This study aims to determine the effect of the fermentation and non-fermentation processes combined with the spray drying process on the quality of instant drink powder of red dragon fruit. In this study, treated red dragon fruit juice was mixed with water in a ratio of 1:3, and pasteurized at $80{ }^{\circ} \mathrm{C}$ first, then cooled. After that proceed with two treatments, namely the anaerobic fermentation process using $S$. cerevisiae at $25^{\circ} \mathrm{C}$ for 10 days, and without the fermentation process. Instant drink powder produced from the spray drying process, from the two treatments there were two formulas, namely non-fermented instant drink (F1) and fermented (F2). The organoleptic results were analyzed by one way ANOVA test and the Bonferroni further test, it was found that F1 was preferred by untrained panelists to F2. In general, the non-fermentation process treatment has more influence on the quality of the red dragon fruit instant drink powder formed, and the formula (F1) is more preferred by the panelists, and can be applied later.

\footnotetext{
Kontributor utama

Email : lukmanjunaidi@gmail.com
} 


\section{Pendahuluan}

Akhir-akhir ini telah berkembang dengan pesat minat konsumen terhadap pangan fungsional (Linnarto, Gunawan, Setiadi, Ashyari, \& Lukman, 2020; Duweini \& Trihaditia, 2017; dan Granato, Branco, Nazzaro, Cruz, \& Faria, 2010). Untuk mengantisipasi potensi pasar tersebut perlu dikembangkan produk pangan fungsional yang dapat memenuhi harapan konsumen. Salah satu sumber pangan fungsional yang potensial adalah buah naga merah. Buah naga merah (Hylocereus polyrhizus) memilki kandungan potassium yang tinggi, kaya serat makanan (Risnayanti, Sabang, \& Ratman, 2015), vitamin C yang tinggi, kaya flavonoid, vitamin B, fosfor, kalsium (Parween, Mandal, \& Hasan, 2018), betasianin, dan senyawa fenolat juga tinggi yang bermanfaat bagi kesehatan (Le \& Le, 2021).

Buah naga dilaporkan memiliki manfaat bagi kesehatan, diantaranya sebagai sumber antioksidan (Risnayanti et al., 2015), dapat membantu dalam mengatasi batuk dan asma, membantu penyembuhan luka (Parween et al., 2018), dan dapat menurunkan kadar gula darah pada penderita penyakit diabetes melitus (Chrisanto, Rachmawati, \& Yulendasari, 2020).

Namun demikian sebagaimana komoditas pertanian lainnya, buah naga mudah rusak jika disimpan pada suhu ruang $\left(25-30{ }^{\circ} \mathrm{C}\right)$, sehingga tidak mudah untuk didistribusikan secara komersil. Istianingsih \& Efendi (2013) menyimpulkan buah naga merah mempunyai daya simpan lebih lama pada suhu penyimpanan $15{ }^{\circ} \mathrm{C}$ yaitu selama \pm 14 hari dibandingkan penyimpanan pada suhu ruang $\left(25-30^{\circ} \mathrm{C}\right)$ selama \pm 7 hari. Salah satu upaya untuk mengatasi permasalahan mudah rusaknya buah naga merah tersebut, dapat dilakukan dengan produksi produk olahan buah naga merah, menjadi minuman fungsional dengan metode fermentasi.

Produk fermentasi adalah salah satu pilihan populer makanan fungsional karena manfaat dan sifat gizinya yang baik. Buah naga merah yang difermentasi memiliki konsentrasi yang tinggi akan fitosterol, betasianin, asam asetat, kandungan fenolik, kandungan flavonoid dan total flavonoid (Foong, Hon, \& Ho, 2012). Selain itu, penelitian yang dilakukan oleh Oktaviani, Puwijantiningsih, \& Pranata (2014) pada minuman probiotik dengan variasi ekstrak buah naga merah menunjukkan bahwa ekstak buah naga merah 100\% menghasilkan kualitas minuman probiotik terbaik.

Berbagai penelitian terkait dengan fermentasi minuman buah naga merah telah dilakukan. Pratiwi, Gunam, \& Antara (2019) melakukan penelitian untuk mengetahui pengaruh penambahan gula dan konsentrasi starter khamir terhadap karakteristik wine buah naga merah yang dihasilkan. Hasil penelitian menunjukkan karakteristik wine buah naga merah yang disukai panelis adalah pada perlakuan penambahan gula sampai $28^{\circ}$ Brix dan konsentrasi starter khamir 15\%. Kadar etanol, gula reduksi, total padatan terlarut $\mathrm{pH}$ dan total fenol berturut-turut yaitu $11,24 \%, 1,76 \%, 12,10^{\circ}$ Brix; 5,75; 1,64 mg/100 g. Tidak terdapat kandungan metanol dalam wine.

Pada penelitian ini salah satu tahap yang dilakukan adalah pasteurisasi. Pasteurisasi merupakan tahapan yang penting untuk preservasi produk pangan. Tujuan utama pasteurisasi adalah untuk mengurangi kandungan mikroorganisme pada produk pangan yang dapat menyebabkan kerusakan atau membahayakan kesehatan konsumen (Ramesh, 2020). Muller, Pasin, Sarkis, \& Marczak (2021), melakukan penelitian terkait dengan pengaruh pasteurisasi menggunakan pemanasan ohmik terhadap Aspergillus fumigatus pada jus apel. Hasil penelitian menunjukkan terdapat perbedaan signifikan pada suhu pasteurisasi $75^{\circ} \mathrm{C}, 80^{\circ} \mathrm{C}$ dan 85 ${ }^{\circ} \mathrm{C}$ dengan inaktivasi lebih cepat selama pemanasan ohmik bila dibandingkan dengan pemanasan konvensional.

Penelitian pengaruh fermentasi dan pasteurisasi terhadap senyawa bioaktif (asam lemak, fitosterol, betasianin dan asam asetat) dan aspek lainnya (sifat fisik, mikrobiologi, kimia dan nutrisi) dari jus buah naga merah (Hylocereus polyrhizus) telah dilakukan oleh Foong et al. (2012). Secara keseluruhan, produk dengan pasteurisasi menunjukkan konsentrasi senyawa bioakif yang lebih tinggi secara signifikan $(\mathrm{p}<0,05)$ dibandingkan dengan produk tanpa pasteurisasi, kecuali asam lemak. Hal ini menunjukkan bahwa perlakuan panas $\left(75^{\circ} \mathrm{C}\right.$ selama 15 detik) dapat memberikan efek yang menguntungkan pada konsentrasi senyawa bioaktif ini. Selain itu, produk dengan pasteurisasi menunjukkan kapasitas penangkapan radikal yang lebih besar $(\mathrm{p}<0,05)$ daripada produk tanpa pasteurisasi. Kesimpulannya, produk dengan pasteurisasi maupun produk tanpa pasteurisasi secara mikrobiologis aman untuk dikonsumsi namun pasteurisasi dapat memberikan efek menguntungkan pada konsentrasi senyawa bioaktif (Foong et al., 2012).

Wong \& Siow (2015) meneliti pengaruh pasteurisasi, $\mathrm{pH}$, penambahan asam askorbat dan penyimpanan terhadap kandungan betasianin dalam jus dan konsentrat buah naga merah. Konsentrat dibuat dengan cara menguapkan jus buah naga merah yang telah dijernihkan dalam rotavapor pada suhu $40{ }^{\circ} \mathrm{C}$. Penambahan asam askorbat $0,25 \%, \mathrm{pH}$ 4,0 dan pasteurisasi pada suhu $65{ }^{\circ} \mathrm{C}$ selama 30 menit, disimpulkan sebagai kondisi proses terbaik untuk mempertahankan kandungan betasianin dalam jus buah naga merah. 
Pengeringan dengan spray drying untuk produksi serbuk jus buah merupakan teknik yang umum digunakan dalam beberapa tahun terakhir karena merupakan teknik yang sederhana, ekonomis dan menguntungkan (Barbosa \& Teixeira, 2017). Berbagai teknik pengeringan tersedia untuk digunakan pada skala industri. Metode yang paling sukses untuk produksi bubuk jus buah adalah freeze drying, foam mat drying dan spray drying. Spray drying adalah teknik yang paling ekonomis menjaga kualitas dengan dehidrasi cepat. Spray drying membuat area permukaan yang besar dalam bentuk tetesan cairan halus melalui atomisasi di ruang pengering, yang kemudian menghasilkan produksi partikel bubuk berbentuk spherical dan teratur (Fazaeli, Emam-Djomeh, Kalbasi, \& Omid, 2012; Turchiuli, Gianfrancesco, Palzer, \& Dumoulin, 2011).

Namum demikian, terdapat beberapa keterbatasan penggunaan spray drying. Meskipun spray drying memiliki waktu kontak pengeringan yang singkat, tetapi melibatkan suhu pengeringan yang relatif tinggi, biasanya suhu udara masuk 150 $220{ }^{\circ} \mathrm{C}$ dan suhu udara keluar $50-80{ }^{\circ} \mathrm{C}$, yang dapat merusak senyawa sensitif, yaitu likopen, $\beta$-karoten, antosianin, vitamin C, warna dan rasa (Patil, Chauhan, \& Singh, 2014 dan Shishir \& Chen, 2017). Selain itu, bahan yang kaya gula, seperti jus buah dan sayuran, sulit untuk langsung diproses dengan spray drying, tanpa bahan pembawa karena sifat lengketnya dan suhu glass transition (Tg) yang rendah, yang menyebabkan masalah deposisi dinding dan kesulitan pengeringan (Shishir \& Chen, 2017).

Bahan pengisi yang paling sering digunakan dalam pengeringan dengan spray drying jus buah dan sayuran adalah maltodekstrin (Tg 100-243 ${ }^{\circ} \mathrm{C}$ ) dan gum arab (Tg $126{ }^{\circ} \mathrm{C}$ ) karena berat molekulnya yang tinggi, suhu Tg yang tinggi serta kelarutan dan viskositas rendah (Shishir \& Chen, 2017 dan Schutyser, Perdana, \& Boom, 2012).

Yuliwaty \& Susanto (2014) melakukan penelitian pengaruh lama pengeringan dan konsentrasi maltodekstrin terhadap karakteristik fisik, kimia dan organoleptik minuman instan daun mengkudu, dengan 2 faktor yaitu lamanya pengeringan ekstrak daun mengkudu (6 jam, 12 jam dan 18 jam) dan konsentrasi maltodekstrin (5\%, 10\% dan 15\%). Hasil perlakuan terbaik berdasarkan parameter fisik dan kimia adalah lama pengeringan 6 jam dengan konsentrasi maltodekstrin 5\% sedangkan perlakuan terbaik menurut parameter organoleptik adalah perlakuan lama pengeringan 18 jam dengan konsentrasi maltodekstrin 10\%.

Tazar, Violalita, Harmi, \& Fahmy (2017), melakukan penelitian terhadap pengaruh perbedaan jenis dan konsentrasi bahan pengisi terhadap karakteristik pewarna buah senduduk (Melastoma malabathricum L.) Hasil penelitian menunjukkan bahwa jenis bahan pengisi yang paling baik dalam pembuatan pewarna bubuk dari buah senduduk adalah maltodekstrin pada konsentrasi 5\% dengan konsentrasi antosianin 7,37 mg/L, kadar air 13,62\%, pH 2,37 dan total asam 41,47\% dengan aktivitas antioksidan sebesar 52,67\%.

Farikha, Anam, \& Widowati (2013), melakukan penelitian yang bertujuan untuk mengetahui pengaruh jenis dan konsentrasi bahan penstabil terhadap sifat fisikokimia (total padatan terlarut, viskositas, stabilitas, $\mathrm{pH}$, aktivitas antioksidan dan kadar vitamin C) sari buah naga merah selama penyimpanan. Hasil penelitian menunjukkan semakin tinggi konsentrasi penstabil maka semakin tinggi total padatan terlarut, viskositas, stabilitas, $\mathrm{pH}$ dan aktivitas antioksidan. Sedangkan kadar vitamin C semakin meningkat ketika konsentrasi gelatin semakin tinggi, tetapi semakin menurun ketika konsentrasi kitosan dinaikkan.

Tujuan dari penelitian ini adalah untuk mengetahui pengaruh proses fermentasi dan non fermentasi yang dikombinasikan dengan proses pengeringan yang menggunakan metode spray drying terhadap mutu serbuk minuman instan dari buah naga merah.

\section{Bahan dan Metode}

\subsection{Bahan}

Bahan yang digunakan pada penelitian ini adalah buah naga merah, air, dan ragi roti (Saccharomyces cerevisae) yang dibeli dari Pasar Bata Putih Kebayoran Lama Jakarta Selatan, akuades, maltodekstrin (dengan nilai DE 16) dan berbagai bahan kimia lainnya untuk uji kadar air, abu, gula, angka lempeng total, kapang dan khamir sesuai SNI.

\subsection{Alat}

Alat yang digunakan adalah pisau, sendok, baskom, kain saring, panci, kompor, jeriken, selang, plastik, termometer kaca air raksa range suhu 0-100 ${ }^{\circ} \mathrm{C}$, labu erlenmeyer (Schott Duran ukuran $1000 \mathrm{ml}$ ), spray dryer (GEA Niro A/S - Denmark) dan alat-alat lainnya untuk uji kadar air, abu, gula, angka lempeng total, kapang dan khamir sesuai SNI ISO 4833-1:2015 dan SNI ISO 2157.2:2012,

\subsection{Metode penelitian}

Pertama-tama dibuat jus buah naga merah, lalu dilanjutkan proses pasteurisasi. Hasil pasteurisasi diperlakukan dengan dua cara, yaitu dengan proses fermentasi menggunakan Saccharomyces cerevisae, dan non fermentasi. Terhadap hasil kedua proses tersebut dilanjutkan proses pengeringan 
menggunakan spray dryer untuk menghasilkan produk akhir yaitu serbuk minuman instan dari buah naga merah hasil non fermentasi (F1), dan fermentasi (F2).

\subsubsection{Proses pengolahan jus buah naga merah}

Pengolahan jus buah naga merah dilakukan sebagai berikut: buah naga merah segar sebanyak 3 kg yang telah dibersihkan dipotong dengan pisau dan diambil daging buahnya kemudian dihaluskan dengan blender, dan disaring dengan kain saring, untuk memperoleh jus buah naga merah tanpa biji. Jus buah naga merah dicampur dengan air yang telah dimasak, dengan perbandingan 1:3, kemudian dipasteurisasi pada suhu $80^{\circ} \mathrm{C}$ lalu didinginkan.

Jus buah naga merah yang dihasilkan dibagi 2 bagian dengan volume masing-masing $1000 \mathrm{ml}$. Satu bagian dengan volume $1000 \mathrm{ml}$ dilanjutkan untuk menghasilkan proses fermentasi, dan yang satu bagian yang lainnya dengan volume $1000 \mathrm{ml}$ dilanjutkan untuk menghasilkan proses non fermentasi. Kedua produk antara tersebut dilanjutkan nantinya dengan proses pengeringan menggunakan spray dryer (suhu inlet $180^{\circ} \mathrm{C}$ dan suhu outlet $80^{\circ} \mathrm{C}$ ) menjadi produk akhir berupa serbuk minuman instan.

\subsubsection{Proses Fermentasi}

Fermentasi jus buah naga merah dilakukan secara statis dengan menggunakan Saccharomyces cerevisae sebanyak 0,25\% per $100 \mathrm{ml}$ jus buah naga merah. Pemilihan konsentrasi Saccharomyces cerevisae didasarkan pada modifikasi konsentrasi dari beberapa literatur (Ni'matusyukriyah \& Swasono, 2020 serta Pratiwi, Gunam, \& Antara, 2019). Saccharomyces cerevisae ditambahkan sejumlah 2,5 g ke dalam $1000 \mathrm{ml}$ jus buah naga merah. Fermentasi dilakukan secara anaerob selama 10 hari (Nguyen, 2014), pada suhu 25-30 ${ }^{\circ} \mathrm{C}$. Diagram alir proses fermentasi dan non fermentasi ditunjukkan pada Gambar 1. Produk (serbuk minuman instan buah naga merah) hasil spray drying segera dimasukkan ke dalam plastik/wadah kedap udara yang kering tertutup rapat, dan disimpan di dalam desikator atau diberi silika gel.

\subsubsection{Proses pengeringan produk antara hasil fermentasi dan non fermentasi dengan metode spray drying}

Maltodekstrin 10\% (b/v) ditambahkan ke dalam masing-masing produk antara yaitu jus buah naga merah tanpa fermentasi dan jus buah naga merah menggunakan proses fermentasi, lalu dicampur, dan dihomogenisasi dengan mixer pada kecepatan 4000 rpm. Setelah homogen, selanjutnya dikeringkan dengan cara dialirkan ke dalam alat spray dryer, dengan kondisi suhu inlet adalah $180{ }^{\circ} \mathrm{C}$, dan suhu outlet adalah $80{ }^{\circ} \mathrm{C}$. Dua produk akhir yang terbentuk adalah serbuk minuman instan dari jus buah naga merah non fermentasi (F1), dan serbuk minuman instan dari jus buah naga merah dengan fermentasi (F2).

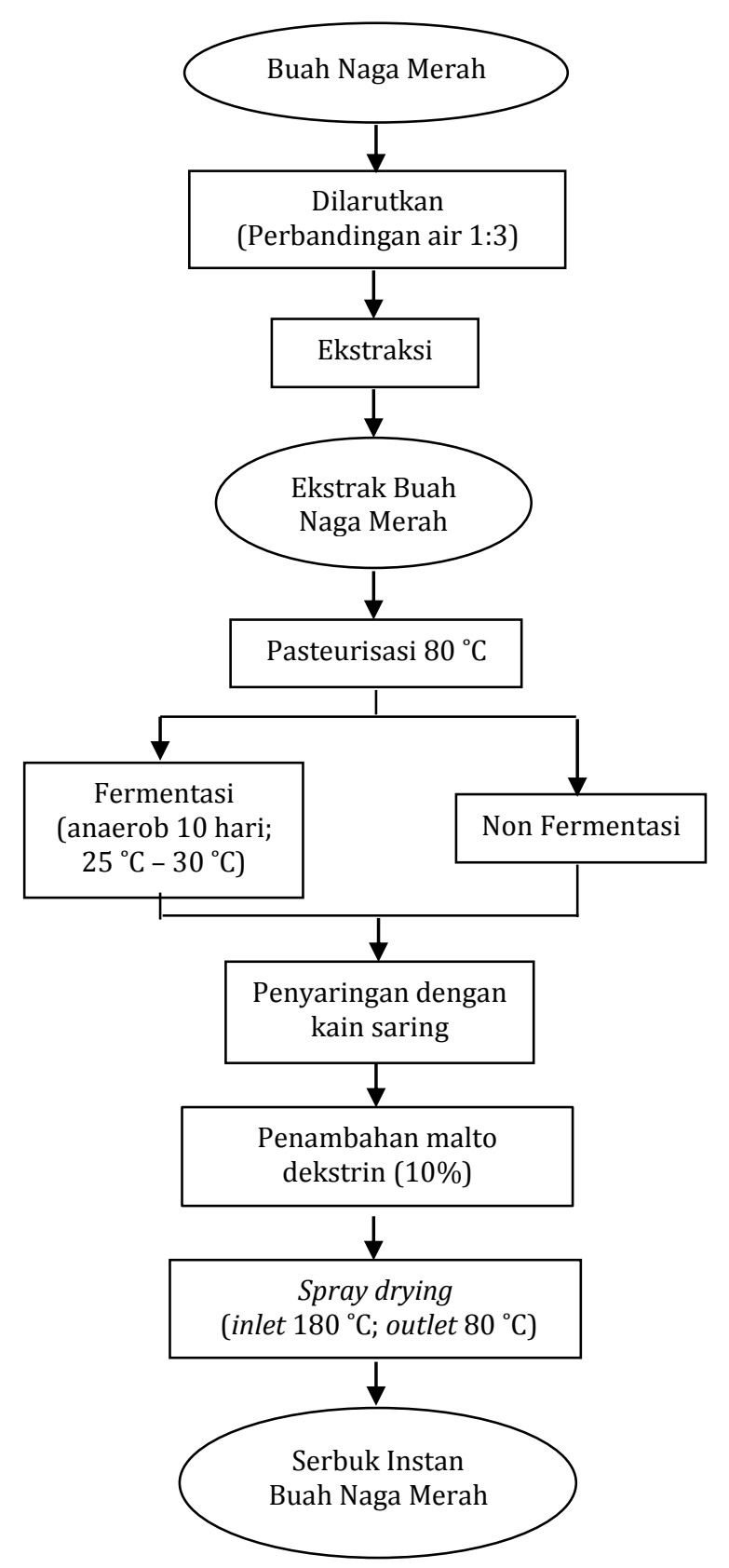

Gambar 1. Diagram alir proses produksi serbuk instan buah naga merah 


\subsection{Analisis terhadap produk akhir serbuk minuman instan}

Analisis dilakukan terhadap produk akhir serbuk minuman instan dengan proses fermentasi (F2), dan non fermentasi (F1) meliputi: kadar air, kadar abu, kadar gula dan pH (SNI 01-2891-1992), angka lempeng total (ALT) (SNI ISO 4833-1:2015), kapang dan khamir (SNI ISO 2157.2:2012), serta organoleptik menggunakan Visual Analog Scale (VAS).

Uji organoleptik dilakukan pada 30 panelis tidak terlatih. Uji organoleptik dilakukan terhadap minuman serbuk instan buah naga merah fermentasi dan non fermentasi, dengan penilaian terhadap warna, rasa, aroma, konsistensi dan tingkat kesukaan. Analisis data pada panel konsumen menggunakan Uji One Way ANOVA karena data tersebut berbentuk komparatif lebih dari dua sampel yang saling berhubungan dan setiap sampel hanya terdiri dari satu kategori.

Hasil uji organoleptik dibandingkan dengan nilai F tabel taraf signifikan 5\%. Apabila hasil yang diperoleh berbeda nyata, maka dilanjutkan dengan uji posthoc test Bonferroni dengan tingkat signifikan $\alpha<0,05$ untuk melihat perbedaan nyata antar perlakuan. Instrumen formulir uji organoleptik menggunakan uji VAS, meliputi: rasa (sangat berasa asam - tidak asam); warna (merah pekat - merah muda); aroma (sangat berasa buah naga merah tidak berasa buah naga merah); konsistensi (sangat kental - sangat cair) dan tingkat kesukaan (sangat tidak suka - sangat suka). Hasil penilaian oleh panelis dinyatakan dalam skor dari pengukuran garis dari $10 \mathrm{~cm}$ (menggunakan VAS) dengan nilai 0100 (O’Mahony, 2017).

\section{Hasil dan Pembahasan}

\subsection{Pengaruh perlakuan fermentasi dan non fermentasi terhadap penerimaan organoleptik}

Produk serbuk instan buah naga merah ditunjukkan pada Gambar 2. Hasil uji organoleptik produk serbuk minuman instan disajikan pada Gambar 3 dan 4. Uji organoleptik hedonik dilakukan pada dua produk. Penilaian hedonik didasarkan indikator warna, konsistensi, aroma dan rasa pada minuman serbuk instan buah naga merah.

Dari hasil analisis uji organoleptik hedonik, produk serbuk minuman instan dari buah naga merah tanpa fermentasi (F1) memiliki nilai lebih tinggi dari produk serbuk minuman instan dari buah naga merah dengan menggunakan proses fermentasi (F2).

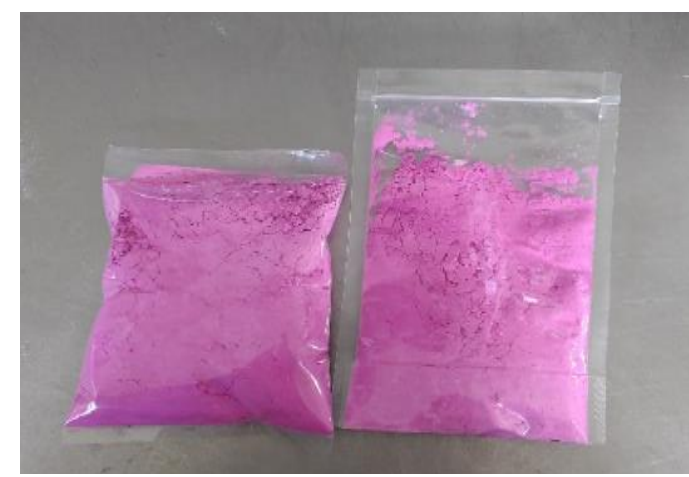

Gambar 2. Produk serbuk instan buah naga merah

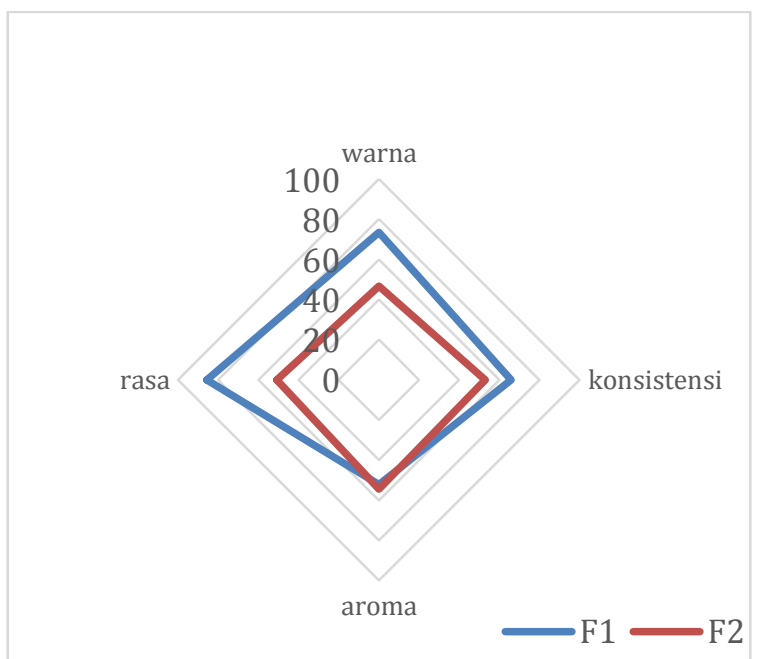

Gambar 3. Nilai uji mutu hedonik minuman serbuk instan

Berdasarkan grafik pada Gambar 3, dapat dilihat bahwa produk F1 memiliki nilai lebih tinggi untuk 3 parameter, yaitu warna, konsistensi dan rasa. Sedangkan untuk parameter aroma, produk F2 memiliki nilai lebih tinggi.

Untuk parameter warna produk F1 memiliki nilai $73,37 \pm 16,91$ dengan rentang penilaian warna ungu muda sampai ungu tua. Untuk parameter konsistensi Produk F1 memiliki nilai 65,97 \pm 18,39 dengan rentang penilaian konsistensi cair hingga kental. Untuk parameter rasa Produk F1 memiliki nilai $85,70 \pm 11,15$ dengan rentang sangat asam hingga tidak asam. Sedangkan untuk parameter aroma produk F2 memiliki nilai 54,53 \pm 26,51 dengan rentang tidak beraroma buah naga merah hingga beraroma buah naga merah.

Berdasarkan grafik pada Gambar 4, dapat dilihat bahwa produk F1 memiliki nilai lebih tinggi pada semua parameter hedonik uji organoleptik serbuk minuman buah naga merah. Untuk parameter warna produk F1 memiliki nilai 82,27 \pm 17,34. Untuk parameter konsistensi produk F1 memiliki nilai $76,63 \pm 19,03$. Untuk parameter aroma produk F1 memiliki nilai $65,17 \pm 29,78$. Sedangkan untuk parameter rasa produk F1 memiliki nilai 75,07 \pm 24,35. Dari grafik pada Gambar 4, dapat dilihat 


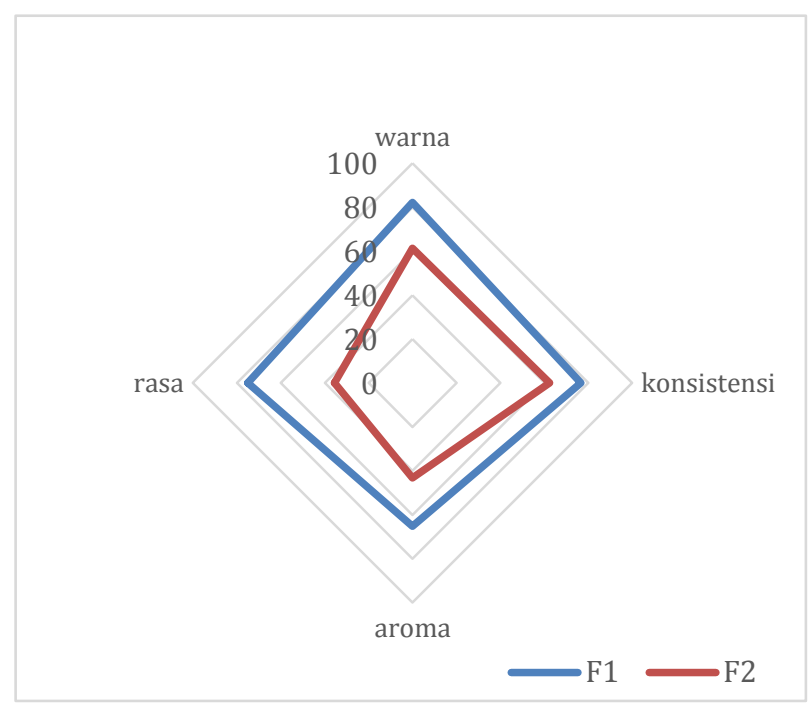

Gambar 4. Nilai uji hedonik minuman serbuk instan

bahwa produk F1 memiliki nilai kesukaan yang lebih tinggi dibandingkan dengan produk F2.

\subsubsection{Warna}

Hasil penelitian menunjukkan adanya perbedaan yang signifikan dari parameter warna pada uji organoleptik dengan nilai $\mathrm{p}(\mathrm{sig})=0,00<0,05$. Minuman serbuk instan F1 cenderung berwarna ungu yang lebih tua bila dibandingkan dengan F2. Hal ini mengakibatkan warna minuman serbuk instan F1 lebih disukai oleh panelis, karena lebih mirip dengan warna buah naga merah dibandingkan warna minuman serbuk instan F2 yang lebih pucat (cerah).

Warna minuman serbuk buah naga merah ini dipengaruhi oleh kadar pH minuman. Diduga hal ini disebabkan oleh terdegradasinya antosianin dari buah naga merah. Berdasarkan pengukuran nilai $\mathrm{pH}$ yang ditunjukkan pada Tabel 1, minuman serbuk instan F1 memiliki pH lebih tinggi dibandingkan dengan $\mathrm{pH}$ minuman serbuk instan F2. Minuman serbuk instan F1 memiliki pH 5,33 sedangkan minuman serbuk instan F2 memiliki pH 4,66.

Fathinatullabibah et al. (2014) menunjukkan bahwa perlakuan $\mathrm{pH}$ dapat mempengaruhi total antosianin. Semakin tinggi nilai pH maka kadar total antosianin semakin menurun. Nilai total antosianin menurun dari mulai pH 3,5 hingga 7,0. Pada suasana asam antosianin berada dalam bentuk garam flavilium berwarna merah yang lebih stabil sedangkan pada $\mathrm{pH}$ yang tinggi warna ekstrak menjadi memudar dan berubah menjadi warna biru (Sartika, 2017). Widaghda dan Choirunnisa (2015) menyebutkan bahwa total antosianin mengalami penurunan setelah difermentasi selama 12 jam. Dengan demikian dapat dinyatakan penurunan antosianin hasil penelitian ini diperkirakan akan lebih besar, mengingat fermentasi pada penelitian ini dilakukan selama 10 hari.

Penurunan nilai total antosianin dapat terjadi karena terdegradasinya pigmen antosianin. Faktorfaktor yang mempengaruhi stabilitas antosianin antara lain oksidasi, peningkatan $\mathrm{pH}$, suhu dan paparan cahaya (Widaghda dan Choirunnisa, 2015).

\subsubsection{Aroma}

Hasil penelitian menunjukkan adanya perbedaan yang signifikan antar perlakuan terhadap nilai aroma. Hal tersebut dikarenakan aroma yang ditimbulkan dari proses fermentasi dengan nilai $p($ sig $)=0,00<0,05$. Hasil analisis uji organoleptik menunjukkan bahwa minuman $\mathrm{F} 1$, yaitu minuman serbuk instan non fermentasi memiliki nilai lebih tinggi daripada produk minuman F2, untuk penilaian hedonik. Panelis lebih cenderung menyukai aroma produk minuman F1 dikarenakan memiliki aroma yang lebih baik daripada minuman lainnya serta memiliki aroma yang lebih mirip seperti buah naga merah pada umumnya. Sedangkan produk minuman F2 memiliki bau asam yang sedikit menyengat yang timbul dari hasil dari fermentasi. Suasana asam pada minuman buah naga merah ini berasal dari proses fermentasi dengan menggunakan $S$. cerevisae. Berdasarkan hal ini dapat disebutkan asam yang terbentuk dari proses fermentasi tidak seluruhnya dapat diuapkan pada proses spray drying. Hal ini diduga karena singkatnya kontak panas produk yang dikeringkan dengan spray drying, serta diperkirakan aroma asam juga terikat ke dalam bahan pengisi maltodekstrin (Shishir \& Chen, 2017).

\subsubsection{Konsistensi}

Hasil dari penelitian ini menunjukkan adanya perbedaan konsistensi yang signifikan antar tiap perlakuan terhadap serbuk minuman instan buah naga merah $\mathrm{p}(\mathrm{sig})=0,00<0,05$. Hasil analisis uji organoleptik menunjukkan bahwa minuman F1, yaitu minuman serbuk instan non fermentasi memiliki konsistensi dengan nilai lebih tinggi daripada produk minuman F2, baik dari hedonik maupun mutu hedonik. Kemungkinan hal ini disebabkan oleh kandungan pektin yang terkandung pada buah naga merah. Pektin yang bermuatan negatif (gugus metil ester) akan mengikat muatan positif $\mathrm{NH}_{3}{ }^{+}$dari protein. Molekul pektin tersebut akan melindungi protein dan akan menutupi secara langsung permukaan molekul protein, sehingga mampu mencegah pengendapan protein (Farikha et al., 2013).

Nilai pH mempengaruhi pembentukan gel oleh pektin. Pektin dapat membentuk gel pada kondisi 
Citation: Junaidi, L., Wijaya, H., Jarief, R. S., \& Angkasa, D. (2021). Pengaruh proses fermentasi dan non-fermentasi serta pengeringan dengan metode spray drying terhadap mutu serbuk minuman instan dari buah naga merah (Hylocereus polyrhizus). Warta IHP, 38(2), 98-107

Halaman | 104

asam tinggi (pH menurun) sehingga menyebabkan meningkatnya kestabilan sari buah. Ketika nilai $\mathrm{pH}$ terlalu tinggi (semakin basa), maka akan terjadi pemecahan pektin oleh enzim metil esterase akan menyebabkan kekentalan dan konsistensi sari buah menurun serta menjadi tidak stabil (Farikha et al,, 2013).

Berdasarkan hasil uji pH yang ditunjukkan pada Tabel 1, dapat dilihat bahwa $\mathrm{pH}$ produk F1, sebesar 5,33 lebih tinggi dari pH produk F2 sebesar 4,66. Oleh karena itu, konsistensi dari produk minuman F2 lebih tinggi dari konsistensi produk minuman F3. Dengan demikian produk minuman F2 terasa lebih kental oleh panelis dibandingkan produk minuman F1. Hal ini diperkirakan mengakibatkan panelis lebih menyukai produk minuman F1.

\subsubsection{Rasa}

Hasil penelitian menunjukkan bahwa adanya pengaruh yang signifikan terhadap rasa pada serbuk minuman buah naga merah $\mathrm{p}(\mathrm{sig})=0,00<0,05$. Hal ini dikarenakan proses fermentasi yang dilakukan sehingga menimbulkan rasa asam pada serbuk minuman buah naga merah. Hasil analisis uji organoleptik menunjukkan bahwa minuman F1, yaitu minuman serbuk instan non fermentasi memiliki rasa dengan nilai lebih tinggi daripada produk minuman F2, baik dari hedonik maupun mutu hedonik.

Produk F2 yang mengalami proses fermentasi akibat adanya aktivitas $S$. cerevisae menghasilkan rasa asam yang kurang disukai oleh panelis. Penurunan $\mathrm{pH}$ karena proses fermentasi jus buah naga merah oleh $S$. cerevisae menjadi sejumlah asam-asam organik, mengakibatkan rasa yang ditimbulkan relatif lebih asam dan tidak disukai oleh para panelis.

\subsection{Pengaruh perlakuan fermentasi dan non fermentasi terhadap mutu serbuk minuman instan}

Hasil analisis karakteristik mutu dilakukan pada kedua sampel untuk melihat pengaruh proses fermentasi dan non fermentasi pada serbuk minuman buah naga merah. Analisis dilakukan oleh Laboratorium BBIA, yang sudah terakreditasi Komite Akreditasi Nasional (KAN), sehingga setiap pelaksanaan uji dilakukan terhadap sampel duplo. Laporan Hasil Uji dari BBIA, mencantumkan nilai rata-rata dari hasil pengujian terhadap sampel duplo tersebut.

Hasil analisis karakteristik mutu disajikan pada Tabel 1. Analisis yang dilakukan meliputi: kadar air, kadar abu, kadar gula, ALT, kapang dan khamir.
Tabel 1.

Hasil Analisis Mutu Serbuk Minuman Instan Dengan Perlakuan Non Fermentasi (F1) dan Fermentasi (F2)

\begin{tabular}{cccc}
\hline Karakteristik & \multicolumn{3}{c}{ Hasil uji } \\
\cline { 2 - 4 } Mutu & F1 & F2 & SNI 01-4320 -1996 \\
\hline Kadar Air (\%) & 3,93 & 4,16 & $<3$ \\
Kadar Abu (\%) & 0,57 & 1,40 & $<1,5$ \\
Kadar Gula (\%) & 47,72 & 38,88 & $<85$ \\
pH & 5,33 & 4.66 & -- \\
ALT (koloni/g) & $5,8 \times 10^{4}$ & $5,0 \times 10^{3}$ & $3 \times 10^{3}$ \\
Kapang (koloni/ml) & $4,9 \times 10^{4}$ & $4,6 \times 10^{3}$ & -- \\
Khamir (koloni/ml) & $<10$ & $<10$ & -- \\
\hline
\end{tabular}

Keterangan:

F1: serbuk minuman instan dari buah naga hasil non fermentasi

F2: serbuk minuman instan dari buah naga hasil fermentasi

\subsubsection{Kadar air}

Dari hasil analisis kadar air yang dilakukan pada penelitian ini diperoleh hasil bahwa produk F2 memiliki kadar air yang lebih tinggi dibandingkan produk F1. Kadar air pada produk F1 sebesar 3,93 $\%$ dan kadar air pada produk F2 adalah 4,16\%. Menurut SNI 01-4320-1996 tentang serbuk minuman tradisonal menyatakan bahwa nilai kadar air untuk standar mutu serbuk minuman tradisional yang dibolehkan adalah 3 - 5\%. Pada Tabel 1 terlihat bahwa untuk kedua produk serbuk minuman instan dari jus buah naga merah hasil non fermentasi (F1), dan fermentasi (F2) memiliki nilai kadar air berturut-turut adalah sebesar 3,93 dan $4,16 \%$. Terlihat bahwa kedua nilai tersebut sudah memenuhi standar mutu serbuk minuman tradisional dan telah sesuai dengan yang dipersyaratkan oleh SNI.

Menurut Widyasaputra \& Yuwono (2013), terjadi peningkatan kadar air pada fermentasi chips 24 hingga 36 jam. Peningkatan kandungan air karena adanya proses metabolisme dari mikroba. Kadar air pada minuman serbuk instan buah naga merah meningkat pada sampel F2 dikarenakan aktifitas enzim yang dihasilkan pada proses fermentasi. Aktivitas enzim tersebut mengakibatkan terjadinya pemecahan ikatan air yang terikat menjadi air bebas.

Penambahan konsentrasi maltodekstrin menyebabkan nilai kadar air produk cenderung meningkat. Pada penelitian ini maltodekstrin yang digunakan adalah maltodekstrin dengan nilai Dextrose Equivalent (DE) tinggi, sehingga memiliki sifat higroskopis. Karena sifat dari maltodekstrin yang bersifat higroskopis (kemampuan menyerap air) menyebabkan kadar air menjadi meningkat seiring dengan penambahan maltodekstrin (Yuliawaty et al., 2014). 


\subsubsection{Kadar $a b u$}

Pada Tabel 1 terlihat bahwa untuk kedua produk serbuk minuman instan dari jus buah naga merah hasil non fermentasi (F1), dan fermentasi (F2) memiliki nilai kadar abu berturut-turut adalah sebesar 1,40 dan $0,57 \%$.

Menurut SNI 01-4320-1996 tentang serbuk minuman tradisonal menyatakan bahwa nilai kadar abu untuk standar mutu serbuk minuman tradisional yang dibolehkan adalah 1,50\%. Terlihat bahwa kedua nilai kadar abu dari produk minuman serbuk instan dari buah naga merah dengan perlakuan fermentasi (F2) dan non fermentasi (F1) sudah memenuhi standar mutu serbuk minuman tradisional dan telah sesuai dengan yang dipersyaratkan oleh SNI. Sehingga untuk semua kadar abu pada serbuk minuman instan buah naga merah sudah memenuhi standar mutu. Hasil penelitian menunjukkan kadar abu dalam serbuk minuman buah naga merah fermentasi lebih tinggi dibandingkan yang tidak fermentasi.

\subsubsection{Nilai $\mathrm{pH}$}

Hasil penelitian menunjukkan serbuk minuman buah naga merah yang difermentasi, memiliki $\mathrm{pH}$ lebih rendah dari serbuk minuman buah naga merah non fermentasi. Nilai pH produk F1 (serbuk minuman non fermentasi) adalah 5,22, sedangkan F2 (serbuk minuman fermentasi) adalah 4,66. Dari data di atas dapat dilihat bahwa serbuk minuman instan buah naga merah yang diperlakukan proses fermentasi (F2), memiliki pH lebih rendah daripada produk F1.

Penelitian yang dilakukan oleh Choo et al. (2018) menyebutkan terjadinya penurunan $\mathrm{pH}$ pada proses fermentasi buah naga merah. Demikian juga Sudiarta, Saputra, Singapurwa, Candra, \& Semariyani (2021), menyebutkan terjadinya penurunan $\mathrm{pH}$ pada proses fermentasi buah naga merah, dari 4,50 menjadi 3,65 - 3,78.

Penurunan $\mathrm{pH}$ terjadi karena selama proses fermentasi khamir mensintesis gula menjadi etanol. Keberadaan oksigen juga akan mengoksidasi etanol menjadi asam laktat sehingga $\mathrm{pH}$ medium akan menurun. Selain itu semakin turunnya nilai $\mathrm{pH}$ produk ini disebabkan oleh hasil fermentasi yang berupa etanol dan $\mathrm{CO}_{2}$. Gas $\mathrm{CO}_{2}$ yang terbentuk akan bereaksi dengan molekul air membentuk $\mathrm{H}_{2} \mathrm{CO}_{3}$ akan memberikan suasana asam pada produk akhir sehingga produk akan memiliki pH yang rendah (Hawusiwa, Wardani, \& Ningtyas, 2015).

\subsubsection{Kadar gula}

Kadar gula total pada produk F1 memiliki kadar gula lebih tinggi daripada F2. Pada penelitian yang dilakukan oleh Hawusiwa et al. (2015) tentang pembuatan minuman wine singkong, total gula mengalami penurunan setelah proses fermentasi. Penurunan ini terjadi karena penggunaan glukosa oleh Saccharomyces cerevisiae untuk dipecah menjadi etanol sehingga jumlahnya akan semakin berkurang.

Total gula pada produk F1 (minuman serbuk non fermentasi) dan F2 (minuman serbuk fermentasi), adalah $47,72 \%$ dan $38,88 \%$. Produk F2 memiliki total gula lebih rendah daripada F1. Kadar gula produk F1 dan F2 memenuhi persyaratan syarat mutu SNI 01-4320-1996 (serbuk minuman tradisonal), yang menetapkan persyaratan kadar gula maksimum $85 \%$.

Ketika fermentasi berlangsung gula akan dikonsumsi sebagai sumber karbon dan dikonversi menjadi alkohol dan $\mathrm{CO}_{2}$ akibat aktivitas $S$. cerevisae. Penurunan total gula selama fermentasi berlangsung terjadi akibat aktivitas $S$. cerevisae yang memecah sukrosa menjadi glukosa dan fruktosa, selanjutnya diubah menjadi alkohol dan $\mathrm{CO}_{2}$. S. cerevisae mengkonversi glukosa melalui siklus glikolisis menjadi etanol dan karbondioksida. Dengan demikian selama fermentasi, gula sebagai sumber karbon akan digunakan untuk memperbanyak sel kemudian gula akan dikonversi oleh sel menjadi etanol (Hawusiwa et al., 2015).

\subsubsection{Uji cemaran mikroorganisme}

Uji cemaran mikroorganisme yang dilakukan meliputi uji Angka Lempeng Total (ALT), uji kapang dan khamir. Hasil uji ALT pada produk serbuk minuman instan, untuk produk F1 sebesar 5,8 x 10 koloni/g dan F2 sebesar 0,5 x $10^{4}$ koloni/g. Batas maksimum cemaran mikroorganisme ALT berdasarkan SNI 01-4320-1996 (SNI Serbuk minuman tradisional) adalah $3 \times 10^{3} \mathrm{koloni} / \mathrm{g}$.

Hasil uji kapang pada produk serbuk minuman instan, untuk produk F1 sebesar 4,9 x $10^{4} \mathrm{koloni} / \mathrm{g}$ dan F2 sebesar 0,46 x $10^{4}$ koloni/g. Penyebab tingginya jumlah kapang pada F1 dan F2 diduga berasal dari berbagai faktor. Kondisi suhu penyimpanan sangat mempengaruhi populasi mikroorganisme yang terdapat dalam makanan. 


\section{Kesimpulan}

Proses fermentasi berpengaruh pada daya terima warna, konsistensi, aroma, dan rasa pada serbuk minuman instan buah naga merah. Secara umum, perlakuan proses non fermentasi lebih berpengaruh terhadap mutu serbuk minuman instan buah naga merah yang terbentuk, dan formulanya (F1) lebih disukai oleh panelis, serta bisa diaplikasikan lebih lanjut. Selain itu, proses fermentasi juga berpengaruh pada kadar air, abu, $\mathrm{pH}$, gula total, ALT dan kapang khamir dari serbuk minuman instan buah naga merah.

\section{Ucapan terima kasih}

Penulis mengucapkan terima kasih kepada Balai Besar Industri Agro yang telah menyediakan fasilitas untuk pelaksanaan penelitian ini.

\section{Daftar Pustaka}

Barbosa, J., \& Teixeira, P. (2017). Development of probiotic fruit juice powders by spray-drying: a review. Food Reviews International,33(4), 335358.

[BSN] Badan Standardisasi Nasional. (1992) Standar Nasional Indonesia Cara uji makanan dan minuman - SNI 01-2891-1992. Badan Standardisasi Nasional Jakarta.

[BSN] Badan Standardisasi Nasional. (1992) Standar Nasional Indonesia Cara uji gula - SNI 01-28921992. Badan Standardisasi Nasional Jakarta.

[BSN] Badan Standardisasi Nasional. (1996) Standar Nasional Indonesia Serbuk minuman tradisional SNI 01-4320-1996. Badan Standardisasi Nasional Jakarta.

[BSN] Badan Standardisasi Nasional. (2012) Standar Nasional Indonesia Mikrobiologi bahan pangan dan pakan - Metode horizontal untuk enumerasi kapang dan khamir - Bagian 2: Teknik penghitungan koloni pada produk dengan aktivitas air kurang dari atau sama dengan 0,95 SNI ISO 21527-2:2012. Badan Standardisasi Nasional Jakarta.

[BSN] Badan Standardisasi Nasional. (2015) Standar Nasional Indonesia Mikrobiologi rantai pangan metode horizontal untuk enumerasi mikroorganisme - Bagian 1: Penghitungan koloni pada suhu $30^{\circ} \mathrm{C}$ dengan teknik cawan tuang - SNI ISO 4833-1:2015. Badan Standardisasi Nasional Jakarta.

Chrisanto, E. Y., Rachmawati, M., \& Yulendasari, R. (2020). Penyuluhan manfaat buah naga merah dalam menurunkan kadar gula darah pada penderita diabetes melitus. Indonesia Berdaya, 1(2), 89-94.
Choo, K.Y., Kho, C., Ong, Y.Y., Thoo, Y.Y., Lim, L.H., Tan, C.P., \& Ho, C.W. (2018). Fermentation of red dragon fruit (Hylocereus polyrhizus) for betalains concentration. International Food Research Journal, 25(6), 2539-2546.

Duweini, M. \& Trihaditia, R. (2017). Penentuan formulasi optimum pembuatan minuman fungsional dari bunga rosella (Hibiscus sabdariffa L.) dengan penambahan bawang dayak (Eleutherine palmifolia (L) merr.) menggunakan metode RSM (response surface method). Agroscience (AGSCI), 7(2), 234-248.

Farikha, I. N., Anam, C., \& Widowati, E. (2013). Pengaruh jenis dan konsentrasi bahan penstabil alami terhadap karakteristik fisikokimia sari buah naga merah (Hylocereus polyrhizus) selama penyimpanan. Jurnal Teknosains Pangan, 2(1), 30 - 38.

Fathinatullabibah, Kawiji, \& Khasanah, L.U. (2014). Stabilitas antosianin ekstrak daun jati (Tectona grandis) terhadap perlakuan $\mathrm{pH}$ dan suhu. Jurnal Aplikasi Tekhnologi Pangan, 3 (2), 60-63.

Fazaeli, M., Djomeh, Z.E., Ashtari, A.K., \& Omid, M. (2012). Effect of spray drying conditions and feed composition on the physical properties of black mulberry juice powder. Food and Bioproducts Processing, 90, 667

Foong, J. H., Hon, W. M., \& Ho, C. W. (2012). Bioactive compounds determination in fermented liquid dragon fruit (Hylocereus polyrhizus). Borneo Science, 31-48.

Granato, D., Branco, G.F., Nazzaro, F., Cruz, A.G., \& Faria, J.A. (2010). Functional foods and nondairy probiotic food development: Trends, concepts, and products. Comprehensive reviews in food science and food safety, 9(3), 292-302.

Hawusiwa, E.S., Wardani, A.K., \& Ningtyas, D.W. (2015). Pengaruh konsentrasi pasta singkong (Manihot esculenta) dan lama fermentasi pada proses pembuatan minuman wine singkong. Jurnal Pangan dan Agroindustri, 3, 147-155.

Istianingsih, T. \& Efendi, D. (2013). Pengaruh umur panen dan suhu simpan terhadap umur simpan buah naga super red (Hylocereus costaricensis). Jurnal Hortikultura Indonesia, 4(1), 54-61.

Le, T.T. \& Le, N.L. (2021). Antioxidant capacities and betacyanin LC-MS profile of red-fleshed dragon fruit juice (Hylocereus polyrhizus) extracted by ultrasound-assisted enzymatic treatment and optimized by response surface methodology. Journal of Food Processing and Preservation, 45(3), e15217.

Linnarto, F.P., Gunawan, K.P., Setiadi, M., Ashyari, R.A., \& Lukman, S. (2020). Teh putih sebagai alternatif minuman fungsional untuk gaya hidup sehat: Peluang komersialisasi di 
Indonesia. Indonesian Business Review, 2(1), 139159.

Muller, W.A., Pasin, M.V.A., Sarkis, J.R., \& Marczak, L.D.F. (2021). Effect of pasteurization on Aspergillus fumigatus in apple juice: analysis of the thermal and electric effects. International Journal of Food Microbiology, 338, 1- 10.

Nguyen, P.M. (2014). Various factors influencing to red dragon fruit (Hylocereus polyrhizus) wine fermentation. Int. J. Multidiscip. Res. Dev, 1, 94-98.

Ni'matusyukriyah \& Swasono, M.A.H. (2020). Pengaruh fortifikasi ekstrak kulit buah naga super merah (Hylocereus costaricensis) terhadap kandungan antioksidan tape singkong kuning (Manihot utilissima Pohl). Teknologi Pangan: Media Informasi Dan Komunikasi Ilmiah Teknologi Pertanian, 11(1), 52-65.

Oktaviani, E.P., Purwijantiningsih, E.L.M., \& Pranata, F.S. (2014). Kualitas dan aktivitas antioksidan minuman probiotik dengan variasi ekstrak buah naga merah (Hyloreceus polyrhizus). E- Journal Univeristas Atma Jaya Yogyakarta, 1, 1-15.

O'Mahony, M. (2017). Sensory evaluation of food: Statistical methods and procedures. New York: Routledge.

Patil, V., Chauhan, A.K., \& Singh, R.P. (2014). Optimization of the spray drying process for developing guava powder using response surface methodology. Powder Technology, 253, 230-236

Perween, T., Mandal, K.K., \& Hasan, M.A. (2018). Dragon fruit: An exotic super future fruit of India.Journal of Pharmacognosy and Phytochemistry, 7(2), 1022-1026.

Pratiwi, A., Elfita, E., \& Aryawati, R. (2012). Pengaruh waktu fermentasi terhadap sifat fisik dan kimia pada pembuatan minuman kombucha dari rumput laut Sargasssum sp. Maspari Journal, 4(1), 131-136.

Pratiwi, R., Gunam, I.B.W., \& Antara, N.S. (2019). Pengaruh penambahan gula dan konsentrasi starter khamir terhadap karakteristik wine buah naga merah.Jurnal Rekayasa dan Manajemen Agroindustri, 7(2), 268-278.

Ramesh, M.N. (2020). Pasteurization and food preservation. In M.S. Rahman (Ed.), Handbook of food preservation (pp. 599-608). Boca Raton: CRC Press.

Risnayanti, R., Sabang, S.M., \& Ratman, R. (2015). Analisis perbedaan kadar vitamin $\mathrm{C}$ buah naga merah (Hylocereus polyrhizus) dan buah naga putih (Hylocereus undatus) yang tumbuh di desa Kolono Kabupaten Morowali Provinsi Sulawesi Tengah. Jurnal Akademika Kimia, 4(2), 91-96.

Sartika, D. (2017). Ekstraksi dan stabilitas antosianin dalam kulit buah naga merah dan daging buah naga merah sebagai pewarna alami (Hylocereous polyrhizus). Unpublished doctoral dissertation, Universitas Pasundan, Bandung.
Shishir, M.R.I. \& Chen, W. (2017). Trends of spray drying: A critical review on drying of fruit and vegetable juices. Trends in food science \& technology, 65, 49-67.

Schutyser, M.A.I., Perdana, J., \& Boom, R.M. (2012). Single droplet drying for optimal spray drying of enzymes and probiotics. Trends in Food Science and Technology, 27, 73-82.

Sudiarta, I.W., Saputra, I.W.R., Singapurwa, N.M.A.S., Candra, I.P., \& Semariyani, A.A.M. (2021). Ethanol and methanol levels of red dragon fruit wine (Hylocereus costaricensis) with the treatment of sugar and fermentation time. In Journal of Physics: Conference Series, 1869(1), 012032.

Tazar, N., Violalita, F., Harmi, M., \& Fahmy, K. (2017). Pengaruh perbedaan jenis dan konsentrasi bahan pengisi terhadap karakteristik pewarna buah senduduk. Jurnal Teknologi Pertanian Andalas, 21(2), 117-121.

Turchiuli, C., Gianfrancesco, A., Palzer, S., \& Dumoulin, E. (2011). Evolution of particle properties during spray drying in relation with stickiness and agglomeration control. Powder Technology, 208(2), 433-440.

Widyasaputra, R. \& Yuwono, S. S. (2013). Pengaruh fermentasi alami chips terhadap sifat fisik tepung ubi jalar putih (Ipomoea batatas L.) terfermentasi. Jurnal Pangan dan Agroindustri, 1(1), 78-89.

Wong, Y.M. \& Siow, L.F. (2015). Effects of heat, pH, antioxidant, agitation and light on betacyanin stability using red-fleshed dragon fruit (Hylocereus polyrhizus) juice and concentrate as models.Journal of food science and technology, 52(5), 3086-3092.

Yuliwaty, S.T. \& Susanto, W.H. (2014). Pengaruh lama pengeringan dan konsentrasi maltodekstrin terhadap karakteristik fisik kimia dan organoleptik minuman instan daun mengkudu (Morinda citrifolia L). Jurnal Pangan dan Agroindustri, 3(1), 41-52. 